\title{
STUDY OF SCIENCE STUDENTS' EXPECTATION FOR UNIVERSITY WRITING COURSES
}

\author{
Shanthi Nadarajan \\ Centre for Language Studies, Universiti Malaysia Sarawak \\ nshanthi@cls.unimas.my
}

\begin{abstract}
The New Malaysia Education Blueprint (2012) states that the private sector continues to have concerns for Malaysian graduates' English proficiency. The present study investigates the views and expectations of science students taking English courses in a public university. The findings revealed that learners saw opportunities to communicate and job applications process as important soft skills. They preferred practical learning methods above traditional teaching methods. Learners considered group performance, personal attitudes and online activities as important learning opportunities, while factual knowledge, report writing were least supported despite the fact that the majority viewed both assessments and instructional process as relevant. The data revealed that though they were dissatisfied with their existing level of proficiency, many students continued to expect an A for their course. An assessment of the learner's' language ability revealed that language ability was less under the learner's control and more dependent on learner proficiency level. Taken together, this study suggests that the curriculum for the Professional Writing course should be highly diversified and balanced, with some emphasis on getting less proficient learners to read and improve their grammar skills while better students should be given opportunities to develop creative talents and interpersonal skills.
\end{abstract}

Keywords: Science students, writing skills, employability, motivation, professional communication

\section{Background}

Malaysia's language education system has undergone several changes over the last three decades. Developments in language policies, greater awareness about language learning and teaching learning and innovations in technology have brought forth a rich variety of resources and assessment tools that have made it possible to address language problems that were once considered remotely possible. Nevertheless, despite these enhancements the new Education Blueprint (Ministry of Education, 2012) continues to state that public perception of the quality of education outcomes remains mixed with expectations continuing to vary across 
different groups. A primary concern is the industry perspective that continues to reveal that there is "... widespread concern about: (i) the lack of higher order thinking skills,... and (ii) the level of graduates' English proficiency." (Ministry of Education, 2012). Interestingly, students themselves continue to remain optimistic with $95 \%$ being quoted in 2011 as agreeing or strongly agreeing that their education helped them develop the right set of life skills. Taken together with a previous national study (Isarji Hj Sarudin, Ainol Madziah Zubairi, Mohamed Sahari Nordi, \& Mohd Azmi Omar, 2008) which found that both industries and students were concerned about the direction of their life skills, it is possible that matters may have changed within these few years but some insights into how students continue to feel about university language courses may be in order. In an effort to optimise learning opportunities and improve undergraduate language performance, a survey was conducted on science students language needs with an aim of understanding more about their expectations and views of a professional writing language course at the university.

\section{Overview}

Learner difference and motivation have been well explored in L2 literature. Gardner (1985) looked at integrativeness and attitudes in terms of the desire to learn the L2 and learner evaluation of the L2 teacher and course. These features have been seen as capable of contributing to some understanding about learner motivation and their performance. Dörnyei (2005) looked at integrativeness in relation to the ideal L2 self, the ought to L2 self and the L2 learning experience. The ideal L2 self is "representative of the ideal image that $L 2$ learners wish to approach in the future (Dörnyei, 2005, p. 106) while the ought to L2 self is the L2 specific aspect of one's ought to self" (Papi, 2010, p. 469). This less internalised aspect of the L2 self refers to the "qualities one perceives one ought to possess to meet expectations and to avoid negative outcomes" as a language learner (Dörnyei \& Ushioda, 2009, p. 29). The following study is motivated by many of these observations.

\section{Method}

In the study data were obtained from 86 undergraduates from three science based programs, namely, Medicine, Resources Science and Cognitives Sciences enrolled in an undergraduate level Professional Writing English course. The undergraduates filled in online questionnaires and participated in two vocabulary tests. The objectives of the writing course were to get learners to construct convincing professional letters, reports and workplace documents in addition to participating in face-to-face professional situations. The aim of the study was to determine the relationship between and within learner personality, language affects, motivation properties and language use. The changes in learners' language ability was assessed through a pre-test post test design but only the results of students who completed both pre-test and post test were used in the language ability findings. 


\section{Results}

The Malaysian University Entrance Test (MUET) band levels were taken as the indicator for learners' perceived intellect at the point of the study. All participants were categorised into three groups based on their bands (e.g., Beginner (Bands 1 \& 2); Intermediate (Bands $3 \& 4$ ) and Advanced (Bands $5 \& 6$ ). Henceforth, all data were analysed according to these three levels.

\section{Perceived competence}

In terms of assessing ideal L2, learners' assumed competence and expectation, the learners' general feeling about the course and their expected grades were analysed. Most students believed the course to be of average difficulty but expected an A for the course irrespective of their initial level (see Table 1). Students were willing to allocate a minimum of 2 to 4 hours to reading the modules every week (see Table 2). However, common comments from students were as below:

"truly... I just spent the time on this subject when there is an assignment to submit. If there is no assignment, there is no time to spend on it"

(Respondent 1)

Table 1

Survey of science students' perceived competence

\begin{tabular}{lllllll}
\hline & \multicolumn{2}{l}{$\begin{array}{l}\text { Subject matter } \\
\text { Muet }\end{array}$} & \multicolumn{5}{l}{ Expected Grade } \\
\hline Band* & Easy & Average & Difficult & A & B & C \\
\hline Beginner & 5 & 85 & 10 & 50 & 45 & 5 \\
Intermediate & 7.9 & 66.7 & 25.4 & 57.1 & 38.1 & 4.8 \\
Advanced & 33.3 & 66.7 & 0 & 100 & 0 & 0 \\
\hline
\end{tabular}

Table 2

Survey of science students' readiness

\begin{tabular}{|c|c|c|c|c|c|c|}
\hline \multirow{2}{*}{$\begin{array}{l}\text { Muet } \\
\text { Band* }\end{array}$} & \multicolumn{3}{|c|}{$\begin{array}{l}\text { Willing to spent on reading for } \\
\text { class } \\
\text { Percentage }\end{array}$} & \multicolumn{3}{|c|}{ Willing to speak in class } \\
\hline & 2 hours & $4 \mathrm{hrs}$ & $>4 \mathrm{hrs}$ & Never & Seldom & Always \\
\hline limited & 35 & 45 & 20 & 10 & 55 & 35 \\
\hline Intermediate & 47.6 & 34.9 & 17.5 & 14.3 & 49.2 & 20.6 \\
\hline Advanced & 0 & 66.7 & 33.3 & 0 & 0 & 100 \\
\hline
\end{tabular}


To investigate learner attitude, students were asked to comment based on their perceptions of their lecture and slides used in class (see Table 3). Satisfaction was high for both lectures and teacher presentation indicating that there was a general level of acceptance for what was being taught. Incidentally, the slides were part of the course materials.

Table 3

Survey of science students' consciousness and attitude

\begin{tabular}{llllll}
\hline MUET & $\begin{array}{l}\text { lectures } \\
\text { Percentage }\end{array}$ & & & \multicolumn{2}{c}{ slides } \\
\hline Band* & focused & relevant & comprehensible & useful & effective \\
\hline limited & 100 & 90 & 95 & 100 & 95 \\
Intermediate & 100 & 95.2 & 95 & 93.7 & 88.9 \\
Advanced & 100 & 100 & 100 & 100 & 100 \\
\hline
\end{tabular}

\section{Language related affect}

The learning situation is an important factor for learner motivation. To assess learner's preferred language learning situations, participants were requested to indicate their preferred learning situations based on a four-point Likert scale (see Table 4). The findings revealed that the learners clearly preferred group activities irrespective of proficiency level closely followed by online activities. Language anxiety was assessed in terms of learners preferred mode of assignment and total time spent on completing course assignments. The preference was for pair and group work (see Table 5). In terms of time spent on all three assignments, most students seem to spend approximately 2 to 4 hours on each assignment (see Table 6). Next, learner satisfaction in terms of most interesting and least interesting course was analysed (see Table 7). A majority of students from the beginner and intermediate groups found the topics on 'Job Application' and 'Mock Interview Process' to be most useful while report writing and grammar was seen by the intermediate group to be less important. The advanced group indicated letter writing to be the most useful skill. One interesting comment from an intermediate learner about the job interview process being as follows:

"The most useful topic is the 'Job Interview' as it give me the chance and lots of knowledge to practice for real job interview."

(Respondent 2) 
Table 4

Survey of science students' preferred learning conditions

\begin{tabular}{|c|c|c|c|c|}
\hline & Frequently & Occasionally & Rarely & Never \\
\hline Beginner & \multicolumn{4}{|l|}{ Percentage } \\
\hline Lectures & 0 & 5 & 40 & 55 \\
\hline Group Activities & 0 & 45 & 35 & 20 \\
\hline Online Activities & 10 & 15 & 40 & 35 \\
\hline Task based Activity & 0 & 15 & 55 & 30 \\
\hline Focused Reading & 0 & 20 & 35 & 45 \\
\hline Intermediate & \multicolumn{4}{|l|}{ Percentage } \\
\hline Lectures & 0 & 9.5 & 38.1 & 52.4 \\
\hline Group Activities & 0 & 20.6 & 47.6 & 31.7 \\
\hline Online Activities & 7.9 & 36.5 & 41.3 & 14.3 \\
\hline Task based Activity & 6.3 & 20.6 & 44.4 & 27.0 \\
\hline Focused Reading & 3.2 & 27.0 & 38.1 & 30.2 \\
\hline Advanced & \multicolumn{4}{|l|}{ Percentage } \\
\hline Lectures & 0 & 33.3 & 0 & 66.7 \\
\hline Group Activities & 0 & 33.3 & 33.3 & 33.3 \\
\hline Online Activities & 0 & 66.7 & 0 & 33.3 \\
\hline Task based Activity & 0 & 66.7 & 0 & 33.3 \\
\hline Focused Reading & 0 & 66.7 & 33.3 & 0 \\
\hline
\end{tabular}

It should be mentioned that the learner seemed to overlook the fact that this was a language course where the emphasis was on getting learners to use accurate and appropriate language and not simulate a discipline specific job application process. Furthermore, in terms of assignments, the general preference was for pair and group work for both beginner and intermediate group though only 60 percent seem to think that they were successful in completing the assignments while the advanced group appeared ambivalent for all three assignment modes though they were confident of their ability to do well in the assignment. In terms of the most useful and least useful topics, learners appeared mixed in their comments. The beginner and intermediate groups were in greater favour of the job interview process while the advanced group were was more interested in the ability to write convincing letters. As for least useful topic, the intermediate group had some students voting in favour of grammar and report writing suggesting that students may be less comfortable with deep processing strategies and in favour or surface learning strategies which may be a cause for concern in the writing classroom. 
Table 5

Survey of science students' preferred mode of assignment

\begin{tabular}{lllll}
\hline Muet & Percentage & & & \\
\hline Band* & Individual & Pair & Group work & Success rate \\
\hline Beginner & 53.2 & 78.9 & 68.4 & 68.4 \\
Intermediate & 56.8 & 86.4 & 75 & 60.2 \\
Advanced & 66.7 & 66.7 & 66.7 & 100 \\
\hline
\end{tabular}

Table 6

Survey of science students' time spent on language assignments

\begin{tabular}{lllll}
\hline Muet & Percentage & & & \\
\hline Band* & 2 hours & 4 hours & 1 day & $>1$ day \\
\hline Beginner & 60.5 & 28.9 & 7.9 & 2.6 \\
Intermediate & 2.3 & 48.9 & 29.5 & 17.0 \\
Advanced & 33.3 & 66.7 & 0 & 0 \\
\hline
\end{tabular}

Table 7

Survey of science students' view on most useful and least useful topic

\begin{tabular}{|c|c|c|c|c|c|c|c|}
\hline & \multicolumn{4}{|c|}{ Most Useful } & \multicolumn{3}{|c|}{ Least Useful } \\
\hline & $\begin{array}{l}\text { Job } \\
\text { interview }\end{array}$ & $\begin{array}{l}\text { Communi- } \\
\text { cation }\end{array}$ & $\begin{array}{l}\text { Letter } \\
\text { writing }\end{array}$ & grammar & none & grammar & $\begin{array}{l}\text { Report } \\
\text { Writing }\end{array}$ \\
\hline Beginner & 85 & 15 & 0 & 0 & 100 & 0 & 0 \\
\hline Intermediate & 45 & 15.9 & 1.6 & 11.1 & 92.1 & 3.2 & 4.7 \\
\hline Advanced & 0 & 0 & 100 & 0 & 100 & 0 & 0 \\
\hline
\end{tabular}

\section{Changes in language ability}

To gauge differences in learners' actual language ability over time, two independent variables were examined to determine different learner's language ability. Only academic and specialised vocabularies were assessed in this study because the emphasis of the course was on getting learners to increase their academic and professional language ability. The paired $t$-test for academic words revealed a statistically reliable difference between the mean of pre-test $(M=7.69, s=4.26)$ and post-test $(M=9.65, s=4.78)$ at $t(51)=-3.201, p=.0 .002$. $\alpha=.05$. The paired $t$-test for specialised words revealed a statistically reliable difference between the mean of pre-test for specialised words at $(M=5.73, s=3.62)$ and post test $(M=7.28, s=4.24)$ at $t(52)=-3.17, p=0.003, \alpha=.05$ suggesting that the differences were significant. 


\section{Discussion and Conclusion}

The data of the present study suggest that the subjects did experience an increase in their language ability in terms of academic and professional vocabulary. The participants viewed job interview, communication and letter writing as important. However, it was the beginner group that viewed the job interview process to be the most useful while the advanced learners seemed biased towards professional letter writing skills. Even within the intermediate groups, there were mixed sentiments in terms of useful courses and less useful courses with some finding letter writing and grammar to be useful while others indicating a preference for grammar and report writing to be shelved from the course. Less proficient students must find both grammar and writing as meaningful in order to master such soft skills. It can be said that a one size fits all teaching approach that includes the latest teaching and technology tools may not be helpful to all. The study also suggest that there is a heavier preference for paired assignments and group assignments even among advanced learners suggesting that assignments should be diversified with additional opportunities for learners to work together even in large classes from time to time. This is to be expected because group learning activities have also been popular with language learners but there is a need to place them in appropriate groups. Furthemore, tests and assignments should be balanced to encourage students to use more factual knowledge and challenging activities. The fact that more than half the class for each level did not like traditional teaching methods like lectures is an added cause for concern because writing is a deep learning process which requires noticing strategies, greater awareness about how words link with one another and opportunities to use the language well in an interesting and novel manner. These experiences can probably be best shared by an informed lecturer. Where this is not possible, learners must be encouraged to read extensively to learn and practise on their own. Unfortunately, reading is not viewed positively in this study. This is a cause for concern because when science students do not want to spend time on their writing, process skills on their own or read beyond their immediate needs, they may not be able to reason and apply critical thinking skills systematically. While group-based writing may be motivating and enjoyable, there is also the need for mastery of factual knowledge in terms of writing types, formats and authors' point of view and ideas must be coherently and cohesively linked and this come with practice and consolidation. The findings from this study is revealing because it focuses on a group that is often assumed to be of a higher intellect and knowledgeable in a number of skills. The implication from this study is that language courses in universities should take into consideration the differences within and between learner levels and learners' intellectual capabilities and provide opportunities for learners to display them. In other words, soft skills should include mastery of factual knowledge, interpersonal communication skills and novel teaching methods that encourage learners to process language in depth, view grammar as important and accept professional writing as necessary for greater employability in the long run. 


\section{References}

Dörnyei, Z. (2005). The Psychology of the language learner: Individual differences in second language acquisition. Mahwah, NJ: Lawrence Erlbaum.

Dörnyei, Z., \& Ushioda, E. (Eds.). (2009). Motivation, language identity and the L2 self. Bristol, UK: Multilingual Matters.

Gardner, R. C. (1985). Social psychology and second language learning: The role of attitudes and motivation. London: Edward Arnold.

Isarji Hj Sarudin, Ainol Madziah Zubairi, Mohamed Sahari Nordi, \& Mohd Azmi Omar. (2008). The English language proficiency of Malaysian public university students. In Zuraidah Mohd Don, Md Yusof Abu Bakar, Nor Aieni Haji Mokhtar, Rohana Jani, Ainol Madziah Zubairi, Norasma Othman \& A. Gan (Eds.), Enhancing the quality of higher education through research: Shaping future policy (pp. 40-65). Malaysia: The Ministry of Higher Education.

Ministry of Education. (2012). The Malaysian education blueprint 2013-2025: Preliminary report. Malaysia.

Papi, M. (2010). The L2 motivational self system, L2 anxiety, and motivated behavior: A structural equation modeling approach. System, 38, 467-479. 